University of Nebraska - Lincoln

DigitalCommons@University of Nebraska - Lincoln

Roman L. Hruska U.S. Meat Animal Research

U.S. Department of Agriculture: Agricultural Center

Research Service, Lincoln, Nebraska

1985

\title{
Energy Utilization by Hereford and Simmental Males and Females
}

Calvin L. Ferrell

U.S. Meat Animal Research Center

Thomas G. Jenkins

U.S. Meat Animal Research Center

Follow this and additional works at: https://digitalcommons.unl.edu/hruskareports

Part of the Animal Sciences Commons

Ferrell, Calvin L. and Jenkins, Thomas G., "Energy Utilization by Hereford and Simmental Males and Females" (1985). Roman L. Hruska U.S. Meat Animal Research Center. 47.

https://digitalcommons.unl.edu/hruskareports/47

This Article is brought to you for free and open access by the U.S. Department of Agriculture: Agricultural Research Service, Lincoln, Nebraska at DigitalCommons@University of Nebraska - Lincoln. It has been accepted for inclusion in Roman L. Hruska U.S. Meat Animal Research Center by an authorized administrator of DigitalCommons@University of Nebraska - Lincoln. 


\section{Energy Utilization by Hereford and Simmental Males and Females}

Calvin L. Ferrell and Thomas G. Jenkins ${ }^{1}$

\section{Introduction}

Observed growth of cattle during the postweaning period reflects the genetic potential for growth as modified by the environment. Various breeds or breed crosses of cattle have been characterized for postweaning liveweight gain under ad libitum feeding conditions. Previous results showed calves by Simmental males had greater rates of postweaning gain than those sired by Hereford males. Simmental-sired steers were more efficient during a weight-constant interval, of equal efficiency during a time-constant interval and less efficient to a fat-constant end point than Hereford-sired steers. Differences among breeds in efficiencies of energy utilization for maintenance and gain have been reported. Similarly, differences among sexes (or sex condition) in growth rate and carcass characteristics have been documented. Efficiencies of energy utilization for maintenance and gain of castrate males have been reported to be similar to those of females. However, other results have suggested that intact males had higher maintenance requirements than castrate males.

This paper describes the accretion of total empty body weight, water, fat, protein, and energy by Hereford and Simmental males and females in response to differing rates of metabolic energy (ME) intake. Estimates of breed and sex effects on ME requirements for maintenance and efficiencies of utilization of $\mathrm{ME}$ for maintenance and gain are reported.

\section{Procedure}

Hereford and Simmental intact males and females (18 of each breed $x$ sex group) were obtained from the research center herds about two weeks after weaning ( 210 days of age). Six calves of each breed $x$ sex group were assigned to one of 12 pens and allowed a 28-day period for adjustment to the diet and to individual feeding by electronic headgates. One pen of calves of each breed and sex was fed a high concentrate diet at a low, medium, or high (ad libitum) level. The diet contains $1.38 \mathrm{Mcal} \mathrm{ME} / \mathrm{lb}$ and 13.9 percent crude protein. Calves were fed individually, once daily, for about 212 days.

One Hereford male (low), two Hereford females (one low, one high), three Simmental males (two high, one low) and two Simmental females (medium) were removed from the study due to failure to adapt to the electronic headgates, poor health, or death. The data reported describe a total of 64 animals that remained on the study.

All calves were weighed at the initiation of the study and at 28-day intervals until completion. The individual food allowances of restricted groups were based on each individual's initial weight. Feed allowances were adjusted at 28-day intervals to maintain daily intakes per unit metabolic body size $\left(\mathrm{kg}^{0.75}\right)$. At 84 days into the study, feed allowances of calves assigned to the restricted levels were adjusted upward because of low or negative weight gains. Unconsumed feed was collected and weighed weekly throughout the feeding period. Samples of feed were taken daily, frozen, composited at 28day intervals, and subsequently analyzed for dry matter and crude protein. On day 0 and about day 212 , deuterium oxide was used to estimate body composition.

\section{Results}

Hereford females weighed less and contained less water and protein but more fat than Hereford males at the start of

'Ferrell is a research animal scientist, Nutrition Unit, and Jenkins is a research animal scientist, Production Systems Unit, MARC. the study (Table 1). Neither liveweight nor any of the empt) body components differed significantly between Simmenta males and females at this time, but Simmental cattle had greate total weights and weights of water and protein than Hereforc cattle. The empty bodies of Hereford males, Simmental males and Simmental females contained similar proportions of watel fat, and protein. Hereford females tended to contain lower pro portions of water, a higher proportion of fat, and a similar pro portion of protein when compared to other animals. These results suggest that Hereford heifers, possibly because of : high propensity toward fatness and a relatively low impetus fo lean growth, had begun to fatten at an earlier age than othe animals included in the study.

Simmental cattle had greater daily ME intakes (Table 2) tha Hereford cattle, and males had greater daily ME intakes tha females. The observed differences reflected, in part, the ex perimental design, since low and medium intakes were gov erned by body size, but also resulted from the initial weight and rates of gain achieved by cattle assigned to the differer treatments. Simmental cattle gained empty body weight slightl faster than Hereford cattle, and males gained weight mor rapidly than females. Hereford males gained fat and energ slightly more rapidly than Hereford females, whereas Sim mental males gained fat and energy less rapidly than Sir mental females. Protein and water gain of Hereford an Simmental cattle were similar at restricted levels of intake, bi gains of these components were greater for Simmental tha for Hereford at ad libitum intakes. Similarly, rates of protei and water gain increased more rapidly in response to increase intake by males as compared to females. Hereford males an females tended to gain energy at similar rates, but Simment males gained energy less rapidly than Simmental females.

These results were consistent with observations made composition of rib section soft tissue of these cattle at slaughte Results of other studies in which breeds or breed crosse differing in growth potential or sex are consistent with da: obtained in this study on cattle fed ad libitum. These resul s further document that at ad libitum intakes, total weight of components of lean tissue (water and protein) gains of Sir mentals were greater than those of Herefords; however, th $s$ advantage was not observed at lower intake levels. Simil results were observed when males were compared to female : These results indicate the benefits that may result from in. creased potential for weight or lean tissue gain may be realize $d$ only if the environment is suitable to support the greater gain 3 .

Simmental cattle had greater $(P<.05) M E$ requirements $f)^{\circ}$ maintenance (energy stasis) than Hereford cattle, and males had greater requirements than females. The ME available for gain did not differ significantly between breed or sex group :, but energy gain of Herefords was greater than that of Sir - mentals. Efficiency of utilization of ME for maintenance or ge in of Herefords was greater than that of Simmentals. These $r$ :sults are consistent with previous reports which showed th t Simmental or Simmental-cross cattle had greater requiremer :s for maintenance than Angus or Hereford cattle. Other repo is indicated Hereford cattle had lower requirements for maint :nance than Holsteins, and that Angus or Hereford steers $h$.d lower predicted basal metabolic rates than Friesian stee s. Results from these and various other studies have often be interpreted to indicate that body protein has a higher ener gy cost of maintenance and a lower efficiency of gain than bo ly fat. Other data has been interpreted to indicate that cattle $w$ th a greater genetic potential for growth have greater main enance requirements than those with less potential for grow 
Table 1.-Initial animal weights and weights of empty body chemical components

\begin{tabular}{lrrrrr}
\hline & \multicolumn{2}{c}{ Hereford } & & \multicolumn{2}{c}{ Simmental } \\
\cline { 2 - 3 } \cline { 5 - 6 } & Male & Female & & Male & Female \\
\hline Jo. of animals & 17 & 16 & & 15 & 16 \\
iveweight, Ib & 514 & 470 & & 666 & 644 \\
:mpty body weight, Ib & 459 & 423 & & 602 & 580 \\
:mpty body water, Ib & 320 & 273 & & 419 & 401 \\
impty body fat, Ib & 30 & 52 & & 38 & 38 \\
impty body protein, Ib & 88 & 80 & & 119 & 111 \\
Impty body energy, MJ & 1,409 & 1,700 & & 1,831 & 1,785 \\
\hline
\end{tabular}

able 2.-Daily metabolizable energy (ME) intake and gains of empty-body components

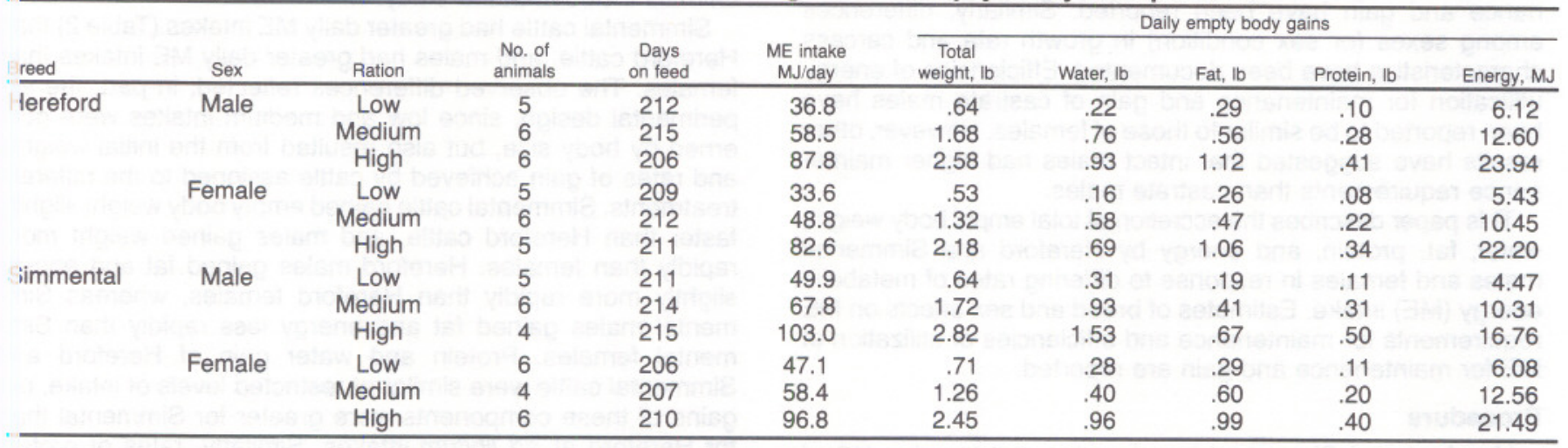

able 3.- Means for utilization of metabolizable energy (ME) by Hereford and Simmental males and females

\begin{tabular}{|c|c|c|c|c|}
\hline \multirow[b]{2}{*}{$3 \mathrm{~m}^{\mathrm{a}}$} & \multicolumn{2}{|c|}{ Breed } & \multicolumn{2}{|c|}{ Sex } \\
\hline & Hereford & Simmental & Male & Female \\
\hline ME intake & 872 & 894 & 898 & 868 \\
\hline | laintenance & 446 & 530 & 514 & 462 \\
\hline IE for gain & 426 & 363 & 385 & 406 \\
\hline nergy gain & 198 & 148 & 165 & 182 \\
\hline l laintenance efficiency & .66 & .62 & .63 & .65 \\
\hline Gain efficiency & .49 & .42 & .43 & .48 \\
\hline
\end{tabular}

